\title{
Inter-Sector and Inter-Country Linkages in Indonesian Economy: World Input-Output Analysis
}

\author{
M. Muchdie ${ }^{1)}$, Muhammad Handry Imansyah ${ }^{2)}$ \\ ${ }^{1}$ Fakultas Ekonomi dan Bisnis, Universitas Muhammadiyah Prof. DR. HAMKA, Jakarta \\ ${ }^{2}$ Fakultas Ekonomi dan Bisnis, Universitas Lambung Mangkurat, Banjarmasin \\ Corresponding Author: eidmuchdie@uhamka.ac.id
}

Recieved: October 2019 | Revised: November 2019 | Accepted: November 2019

\begin{abstract}
Results of analysis on inter-sector and inter-country linkages in Indonesian economy using world inputoutput data are presented in this paper. The model was aggregated from 56 sectors and 43 countries into 30 sectors and 8 countries. Inter-sector linkages are analyzed using forward and backward effect indices. Meanwhile inter-county linkage is analyzed by spill-over and feed-back effects. The results showed thatfirstly, number of sectors include in Group-1, namely key sectors with strong forward and backward linkages: two sectors in year 2000, one sector in year 2005, 8 sectors in year 2010 and 2014. Secondly, spill-over effects were significantly importance in Indonesia economy, as around 20 per cent of multipliers occurred in other countries. Only small feed-back effects are in Indonesian economy. Finally, ignoring inter-country feed-back could be misleading as error created was significant.
\end{abstract}

Keywords: inter-sector linkages, inter-country linkages, world input-output tables, Indonesian economy. JEL Classification: C67, D57, N90, O57

How to Cite: Muchdie, M., \& Imansyah, M. (2019). Inter-Sector and Inter-Country Linkages in Indonesian Economy: World Input-Output Analysis. Jurnal Ekonomi Pembangunan: Kajian Masalah Ekonomi dan Pembangunan, 20(2). doi:https://doi.org/10.23917/jep.v20i2.9057

DOI: https://doi.org/10.23917/jep.v20i2.9057

\section{Introduction}

Assessment of sectoral and spatial economic performance is very important issues in forming development policies. In a competitive economy, sectoral and spatial interdependences are of the most important sources of economic expansion. Sectoral linkages, comprising backward (BL) and forward linkages (FL), reflect the interconnectedness between the sectors of an economy. The idea of linkages grew out of Hirschman's theory of unbalanced growth and describes the relationships that exist between parties involved along the supply chain. BL describes the process of how a company in a given sector purchases its goods, products, or supplies from a company in a different sector; these are called inputs. FL describes the process of how a company in a given sector sells its goods, products, or supplies to a company in a different sector; these are called outputs. BL and FL analysis have been used to determine key sectors in development planning. Several studies have been conducted on sectoral linkages by many researchers (Rueda-Cantuche, Neuwahl, \& Delgado, 2012; Midmore et al., 2006; Cai \& Leung, 2004; Cai, Leung, Pan, \& Pooley, 2005; Rashid, 2004 ; Hoen, 2002; Andreosso-Callaghan \& Yue, 2004; Sonis, Hewings, \& Guo, 2000; Hewings \& Fonseca, 1989; Hewings, 1982; Beyers, 1976)

Inter-country or spatial linkages consist of spill-over effect (SOE) and inter-country feed-back effect (FBE). Measures of inter-regional feed-back and spill-over linkages have been developed by among others(Miller, 1986; Miller \& Blair, 2009; Miller, 1966;Guccione, Gillen, Blair, \& Millert, 1988; Cochrane, 1990; Dietzenbacher, 2002;Dietzenbacher $\&$ Linden, 1997). The importance of inter-country connection for a country could be shown by calculating 
Jurnal Ekonomi Pembangunan: Kajian Masalah Ekonomi dan Pembangunan, 20 (2), 2019, 232-245

output forthcoming from sectors in a country in response to a change in that county's final demands under two alternative assumptions, firstly that the country is a fully-connected part of an inter-country input-output system, and secondlythat the country is totally isolated from the remaining regions. Using Inter-Country Feed-Back Index (ICFBI) and FeedBack and Spill-Over Index (FBSOI), the importance of inter-country linkages among country could also be clearly indicated.

The purpose of this paper aims to analyze inter-sector linkage through FLand BL and intercountry linkage through spill-over effectand feedback effectin Indonesian economy using world inputoutput analysis for year 2000, 2005, 2010 and 2014.

\section{Research Method}

The World Input-Output Database (WIOD) that provides annual time-series of world inputoutput tables from 1995 onwards. These tables have been constructed in a clear conceptual framework based on the system of national account(United Nation, 2018). They are based on officially published input-output tables merged with national accounts data and international trade statistics. In addition, the WIOD provides data on factor inputs enlarging the scope of potential applications considerably. Since its public inception on April 2012, WIOD has proved very useful in analyses of international trade. It has been used to describe trends in global supply chain trade and research into the formation of regional production clusters in the world economy(Baldwin \& Lopez-gonzalez, 2014;Los, Timmer, \& Vries, 2014; Timmer, Los, Stehrer, \& de Vries, 2013)as well as analysing the domestic value-added content of gross exports (Wang, Zhu, \& Wei, 2018initially proposed by Koopman, Wang, and Wei (2014; Koopman, Wang, \& Wei, 2014; Johnson, 2014). The data also proved suitable for calibrating general equilibrium models to evaluate the effects of trade policies(Costinot \& Rodríguez-clare, 2018; Dhingra, Huang, Ottaviano, Sampson, \& April, 2016). The cross-section panel dimensions of the data allowed a revisit of the debate on the effects of off shoring on labour demand(Fostermcgregor, Stehrer, \& de Vries, 2013). WIOD also found its way into numerous policy-oriented studies on the effects of globalization (Mauro \& Plamper, 2013; Saito, Ruta, \& Turunen, 2013).

Table 1: Simplified World Input-Output Table

\begin{tabular}{|c|c|c|c|c|c|c|}
\hline $\begin{array}{c}\text { CountryA } \\
\text { Intermediate } \\
\text { Input } \\
\left({ }^{\mathrm{AA}} \mathrm{X}_{\mathrm{ij}}\right)\end{array}$ & $\begin{array}{c}\text { Output } \\
\text { Exported } \\
\text { to Country B } \\
\left({ }^{\mathrm{AB}} \mathrm{X}_{\mathrm{ij}}\right)\end{array}$ & $\begin{array}{c}\text { Output } \\
\text { Exported } \\
\text { to Country } C \\
\left({ }^{\mathrm{AC}} \mathrm{X}_{\mathrm{ij}}\right)\end{array}$ & $\cdots$ & $\begin{array}{c}\text { Output } \\
\text { Exported } \\
\text { to Country } \\
Z \\
\left({ }^{\mathrm{AZ}} \mathbf{X}_{\mathrm{ij}}\right)\end{array}$ & $\begin{array}{l}\text { Other } \\
\text { FD } \\
\left({ }^{A} D_{j}\right)\end{array}$ & $\begin{array}{c}\text { Total } \\
\text { Output } \\
\left({ }^{A} \mathbf{X}_{j}\right)\end{array}$ \\
\hline \multicolumn{7}{|l|}{$\begin{array}{c}\text { InputImported } \\
\text { from } \\
\text { Country } B\left({ }^{\mathrm{BA}} X_{\mathrm{ij}}\right)\end{array}$} \\
\hline \multicolumn{7}{|l|}{$\begin{array}{c}\text { Input } \\
\text { Importedfrom } \\
\text { Country } C\left({ }^{\mathrm{C} A} \mathbf{X}_{\mathrm{ij}}\right)\end{array}$} \\
\hline \multicolumn{7}{|l|}{ : } \\
\hline \multicolumn{7}{|l|}{$\begin{array}{l}\text { Input Imported } \\
\text { from } \\
\text { Country } Z\left({ }^{Z A} X_{i}\right)\end{array}$} \\
\hline \multicolumn{7}{|l|}{$\begin{array}{c}\text { Other VA } \\
\left({ }^{\mathrm{A}} \text { VA }\right. \\
\left.\mathrm{i}_{\mathrm{i}}\right)\end{array}$} \\
\hline $\begin{array}{l}\text { Total Input } \\
{ }_{\left({ }^{A} X_{i}\right)}\end{array}$ & & & & & & \\
\hline
\end{tabular}

Source: Timmer et al., 2016 
Basically, a world input-output table (WIOT) is an extension of national input output table. The difference with the national tables is that the use of products is broken down according to their origin and destination countries(Timmer, Los, Stehrer, \& De Vries, 2016; Dhehibi, Bahri, \& Annabi, 2012). A world input- output table (WIOT) can be regarded as a set of national input-output tables that are connected with each other by bilateral international trade flows. This is illustrated in Table 1.

WIOT provides a comprehensive summary of all transactions in the global economy between industries and final users across countries. The columns in the WIOT contain information on production processes. When expressed as ratios to gross output, the cells in a column provide information on the shares of inputs in total costs. Such a vector of cost shares is often referred to as a production technology. Products can be used as intermediates by other industries or as final products by households and governments (consumption) or firms (stocks and gross fixed capital formation).The distribution of the output of industries over user categories is indicated in the rows of the table. An important accounting identity in the WIOT is that gross output of each industry (given in the last element of each column) is equal to the sum of all uses of the output from that industry (given in the last element of each row). In addition to a national input-output table, imports are broken down according to the country and industry of origin in a WIOT. This allows one, for example, to trace the country of origin of the chemicals used in the food industry of country A.

The columns of Table 1 provide information on the input composition of the total supply of each product $j\left(\mathrm{X}_{\mathrm{j}}\right)$, this is comprised by the national production and also by imported products. The value of domestic production consists of intermediate consumption of several industrial inputs $i$ plus value added. The inter-industry transactions table is a nuclear part of this table, in the sense that it provides a detailed portrait of how the different economic activities are interrelated. Since intermediate consumption is of the total-flow type, this implies that true technological relationships are being considered. In fact, each column of the intermediate consumption table describes the total amount of each input $i$ consumed in the production of output $j$, regardless of the geographical origin of that input.

The second release of the WIOD in November 2013 provides a time-series of world input-output tables (WIOTs) from 1995 to 2011. It covers 40 countries, including all 27 members of the EU and 13 other major economies: Australia, Brazil, Canada, China, India, Indonesia, Japan, Mexico, Russia, South Korea, Taiwan, Turkey and the USA(Timmer et al., 2016). WIOD 2016 release covers all trade between 43 countries as well as with a "rest-of-the world" region(Timmer, Dietzenbacher, Los, \& Stehrer, 2015). For the purpose of this study, model is aggregated into 6 Asian countries: China, Indonesia, India, Japan, Korea, and Taiwan, plus Australia and the United States. Sectors are aggregated from 56 sectors to 30 sectors as provided in Appendix-1. Data processed are data for year 2000, 2005, 2010 and 2014.

Inter-sector linkages, comprising backward (BL) and forward linkages (FL), reflect the interconnectedness between the sectors of an economy. FL describes the process of how a company in a given sector sells its goods, products, or supplies to a company in a different sector. BL describes the process of how a company in a given sector purchases its goods, products, or supplies from a company in a different sector and different country. In the literature on interindustry linkages, BL and FL are widely accepted concepts, but there remains discussion over how best to measure them(Jones, 1976;Hewings, 1982; Cella, 1984; Sonis \& Hewings, 2009; Miller \& Lahr, 2001; Cai \& Leung, 2004). In this paper, the suggestion byCai et al., (2005) is employed; the Leontief supply-driven multiplier (LSD) as a backward-linkage measure and the Ghosh supplydriven multiplier (GSD) as the corresponding forward-linkage measured by Cai \& Leung (2004) and Leung \& Pooley (2002)for similar applications 
of these supply-driven multipliers.

In brief, the LSD multiplier provides information about an industry's existing relationships with its upstream suppliers; specifically, it measures the dollar amount of production needed directly and indirectly by the industry from its (upstream) suppliers to generate one dollar of sales. The GSD multiplier describes numerically an industry's relationship, directly and indirectly, with its downstream buyers.FL index is calculated by dividing its GSD multiplier by the average GSD multipliers for all the industries.

$\mathrm{FL}_{\mathrm{i}}=$ GSD multiplier for sector-i/Average

GSD multiplier for all industries

BL index for $\mathrm{i}$ is simply the industry's LSD multiplier divided by the average LSD for all the industries.

$\mathrm{BL}_{\mathrm{i}}=\mathrm{LSD}$ multiplier for sector i/Average LSD multiplier for all industries

Depending on the values of their BL and FL indices, the sectors are grouped into 4 categories:

Group-1 : Strong backward and forward linkages (BL $>1 ; \mathrm{FL}>1$ ),

Group-2: Strong backward, but weak forward linkages (BL $>1 ; \mathrm{FL}<1)$,

Group-3 : Weak backward, but strong forward linkages (BL $<1 ; \mathrm{FL}>1)$, and

Group-4 : Weak backward and forward linkages $(\mathrm{BL}<1 ; \mathrm{FL}<1)$.

The spatial spill-over effects are calculated as the difference between the total multiplier in single-country model and the multiplier effects that occurred in own-region, in inter-country model. SOE is the multiplier effects that occur in other country due to the change of final demand of own country. Spatial feed-back effects of multipliers can easily be shown by the difference between the single-region multipliers and the intra-country multipliers, those multipliers that occur in own-country of the inter-country model. FBE is calculated as differences between intra-country multipliers in inter-country model and total multipliers in single-country model. Percentage error of ignoring the inter-country linkages is measured using ICFBI (Inter-Country Feed-Back Index) and FBSOI (Feed-Back and Spill-Over Index). ICFBI is ratio of feed-back effect multipliers to total multipliers in single-country model. FBSOI is ratio of feed-back and spill-over multipliers to total multipliers in inter-country model.

\section{Results and Discussion}

\subsection{Inter-Sector Linkages: Forward and Backward}

Figure 1 presents result of calculations on forward and backward linkages in Indonesian economy for year 2000, 2005, 2010 and 2014. As Sector-23 is omitted from the model, there are 29 sectors in Indonesian economy. In year 2000, average forward linkage (FL) in Indonesian economy was 0.4656 with maximum FL of 1.2971 (Sector-15). Only three sectors had strong FL indicated with FL more than 1. These sectors are: Sector-2 (1.0126), Sector-8 (1.0058) and Sector-15 (1.2971). Other 16 sectors had weak FL indicated with less than 1. Average backward linkage (BL) was 0.8994.There are 16 sectors with strong BL, namely: Sector-5 (1.1271), Sector-6 (1.1019), Sector-7 (1.0878), Sector-8 (1.1525), Sector-11(1.1218), Sector-12 (1.1316), Sector-13 (1.1506), Sector-15 (1.2342), Sector-16 (1.1204), Sector-17 (1.1897), Sector-18 (1.1194), Sector-19 (1.1539), Sector-21 (1.1493), Sector-22 (1.1664), Sector-24 (1.2493), and Sector-25 (1.1254). Other 13sectors had BL less than 1; sectors with weak BL.

In year 2005, average FL in Indonesian economy was 0.4009 with maximum FL of 1.2861 (Sector-15). Only 1 sector had strong FL, namely Sector-15 (1.2861). Other 28 sectors had weak FL; sectors with FL less than 1 . In this year, average BL in Indonesian economy was 0.8929 . There are 13 sectors with strong BL are: Sector-5 (1.1104), Sector-6 (1.0851), Sector-8 (1.0773), Sector-9 (1.0808), Sector-11 (1.1757), Sector-12 (1.2022), Sector-13 (1.2328), Sector-15 (1.2703), Sector-16 (1.0656), Sector-17 (1.0981), Sector-18 (1.0836), 
Jurnal Ekonomi Pembangunan: Kajian Masalah Ekonomi dan Pembangunan, 20 (2), 2019, 232-245

Sector-19 (1.2423), Sector-21 (1.1507), Sector-22 (1.0954), Sector-24 (1.1941) and Sector-25(1.0927). Other 16sectors had BL less than 1; sectors with weak BL.

In year 2010, average FL in Indonesian economy was 0.9521 . There are 13 sectors with strong FL indicated by FL more than 1 included Sector-1 (1.0367), Sector-2 (1.5255), Sector-4 (1.5864), Sector-7 (1.5311), Sector-8 (1.5564), Sector-9 (1.5993), Sector-10 (1.2103), Sector-11 (1.4789), Sector-13 (1.3037), Sector-14 (1.4260), Sector-15 (1.5842), Sector-16 (1.5299) and Sector-24 (1.1147). Other 16sectors had FL less than 1. In 2010, average BL was 0.9016. There are 16 sectors that had strong BL indicated by FL more than 1 included Sector-5 (1.1577), Sector-8 (1.1220), Sector-9 (1.2237), Sector-11 (1.1123), Sector-12 (1.1241), Sector-13 (1.2471), Sector-14 (1.1030), Sector-15 (1.1544), Sector-16 (1.0861), Sector-17 (1.2448), Sector-18 (1.1618), Sector-19 (1.2553), Sector-21 (1.0064), Sector-22 (1.0375), Sector-24 (1.2888) and Sector-25 (1.1137). Other 13sectors had weak BL, sectors with BL less than 1.
In year 2014, average FL in Indonesian economy was 0.9317 . There are 13 sectors with strong FL, namely Sector-1 (1.0020), Sector-2 (1.4955), Sector-4 (1.5612), Sector-7 (1.5176), Sector-8 (1.5227), Sector-9 (1.5706), Sector-10 (1.2073), Sector-11 (1.4446), Sector-13 (1.3102), Sector-14 (1.4089), Sector-15 (1.5578), Sector-16 (1.5014), and Sector-24(1.0792). Other sectors 16 had FL less than 1. Meanwhile, average BL in this year was 0.9017.There are 16 sectors had strong BL, namely Sector-5 (1.1562), Sector-8 (1.1194), Sector-9 (1.2212), Sector-11 (1.1081), Sector-12 (1.1217), Sector-13 (1.2427), Sector-14 (1.0996), Sector-15 (1.1510), Sector-16 (1.0850), Sector-17 (1.2443), Sector-18 (1.1609), Sector-19 (1.2530), Sector-21 (1.0218), Sector-22 (1.0354), Sector-24 (1.2898), and Sector-25 (1.1116). Other 13sectors had BL less than 1.

During the years of study, more sectors with strong BL than sectors with strong FL in Indonesian economy. BL are more strength than FL. Development priorities should be given to the sectors that have both strong BL and FL as well.

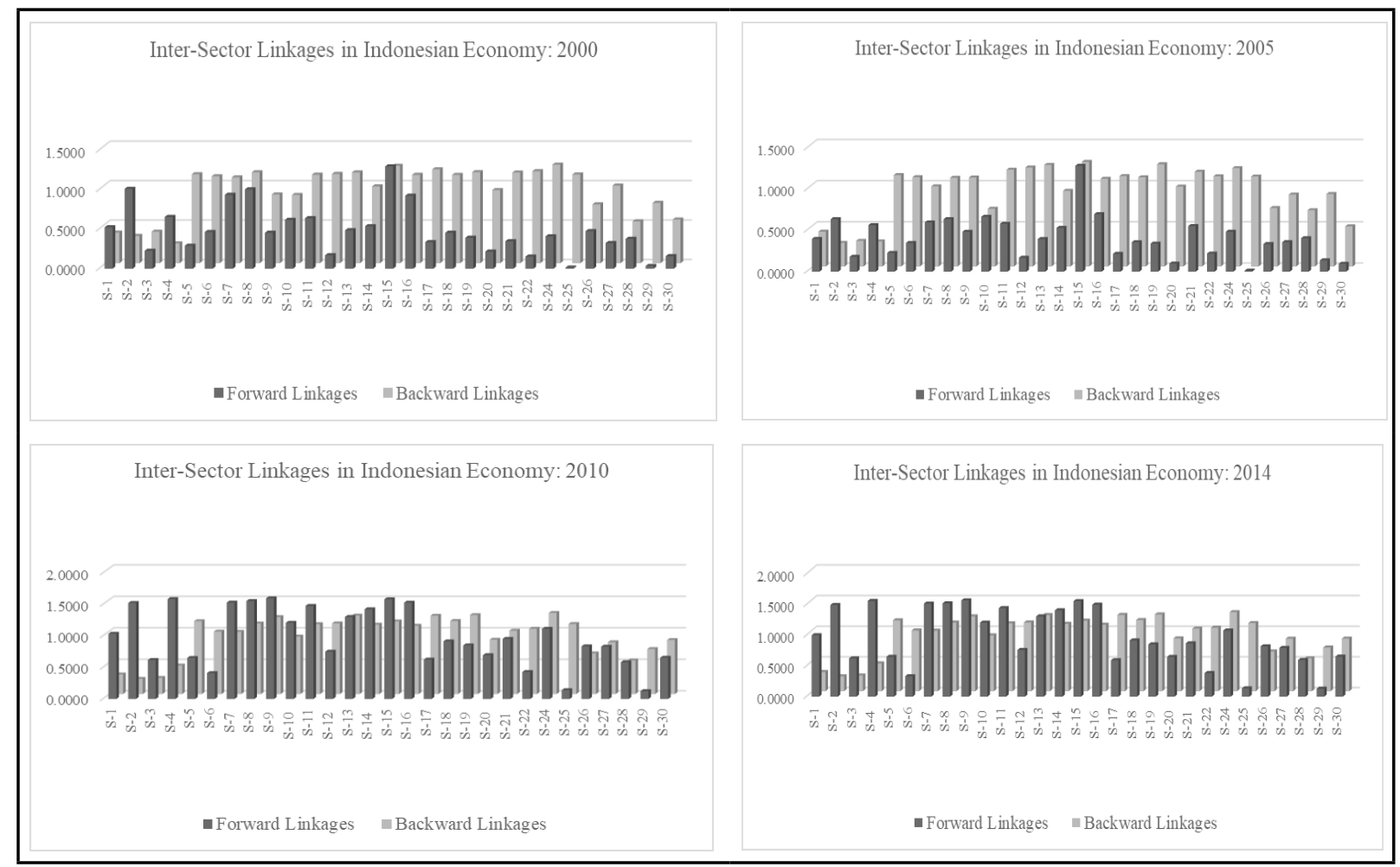

Figure 1: Indonesia's Forward and Backward Linkages: 2000, 2005, 2010, and 2014 


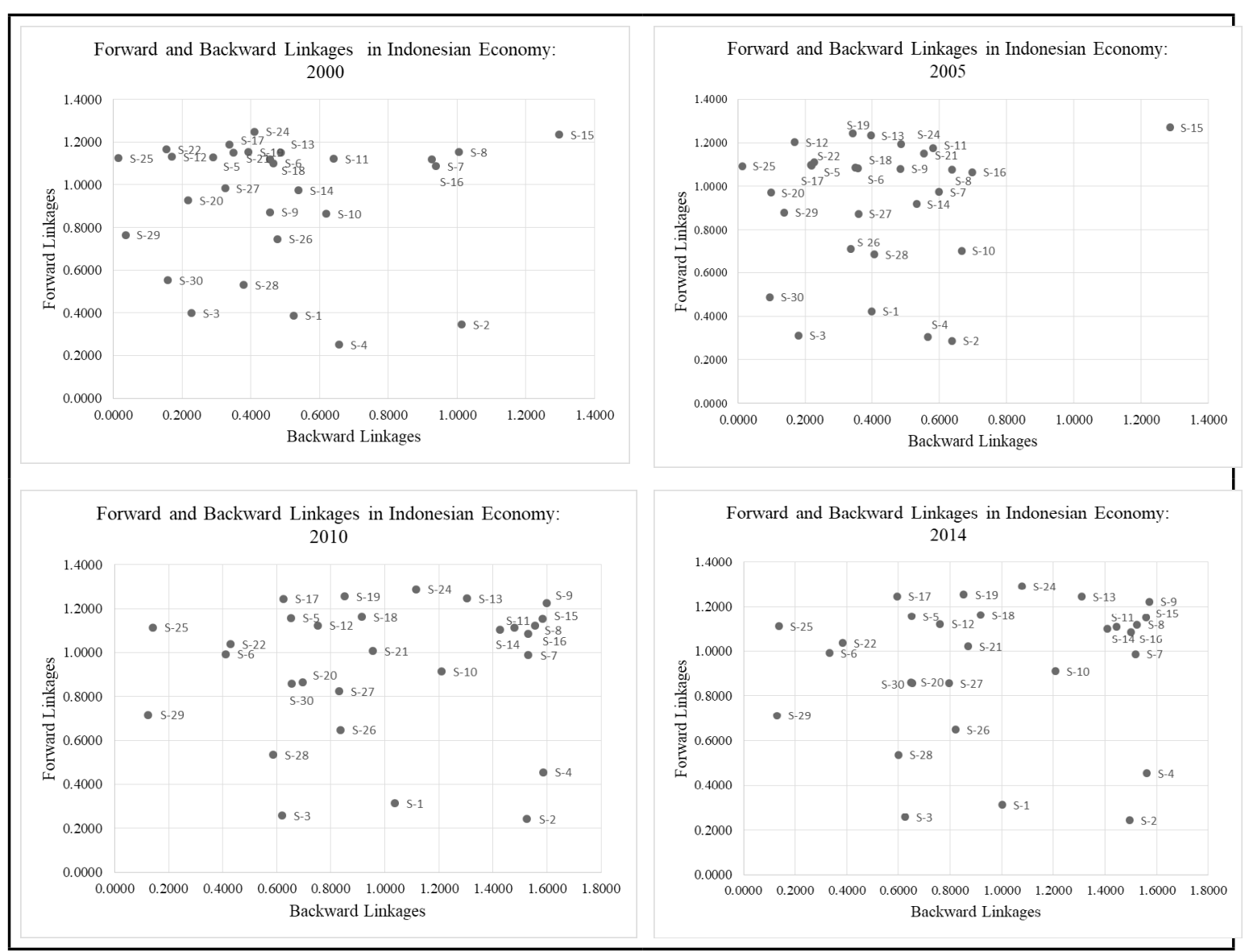

Figure 2: Sector's Position Based on Forward and Backward Linkages in Indonesian Economy: 2000, 2005, 2010 and 2014.

Figure 2 groups Indonesian economic sectors based on FL and BL for year 2000, 2005, 2010 and 2014. Group-1: strong FL (FL $>1)$ and strong BL (BL>1); Group-2: strong FL $(\mathrm{FL}>1)$ but weak BL (BL<1); Group-3: weak FL (FL $<1)$ but strong BL $(\mathrm{BL}>1)$ and Group-4: weak FL $(\mathrm{FL}<1)$ and weak BL $(B L<1)$. In year 2000, only two sectors were in Group-1, namely Sector-8 and Sector-15. One sector was in Group-2 (Sector-2). Fourteen sectors were in Group-3, namely Sector-5, Sector-6, Sector-7, Sector-11, Sector-12, Sector-13, Sector-16, Sector-17, Sector-18, Sector-19, Sector-21, Sector-22, Sector-24, Sector-25, and 12 sectors were in Group- 4, namely: Sector-1, Sector-3, Sector-4, Sector-9, Sector-10, Sector-14, Sector-20, Sector-26, Sector-27, Sector-28, Sector-29, and Sector-30.
In year 2005, only 1 sector was in Group-1, namely Sector-15. No sector was in Group- 2. Fifteen sectors were in Group-3, namely: Sector-5, Sector-6, Sector-8, Sector-9, Sector-11, Sector-12, Sector-13, Sector-16, Sector-17, Sector-18, Sector-19, Sector-21, Sector-22, Sector-24, Sector-2) and 13 sectors were in Group-4, namely: Sector-1, Sector-2, Sector-3, Sector-4, Sector-7, Sector-9, Sector-10, Sector-14, Sector-20, Sector-26, Sector-27, Sector-28, Sector-29, and Sector-30.

In year 2010, 8 sectors were in Group-1, namely: Sector-8, Sector-9, Sector-11, Sector-13, Sector-14, Sector-15, Sector-16, and Sector-24. Five sectors were in Group-2, namely: Sector-1, Sector-2, Sector-4, Sector-7, and Sector-10. Eight sectors were in Group-3 (Sector-5, Sector-12, 
Sector-17, Sector-18, Sector-19, Sector-21, Sector-22, and Sector-25. Group-4 consists of 8 sectors, namely: Sector-3, Sector-6, Sector-20, Sector-26, Sector-27, Sector-28, Sector-29, and Sector-30.

In year 2014, 8 sectors were in Group-1, namely: Sector-8, Sector-9, Sector-11, Sector-13, Sector-14, Sector-15, Sector-16, and Sector-24. Group-2 consists of 5 sectors, namely: Sector-1, Sector-2, Sector-4, Sector-7, and Sector-10. Group-3 consists of 8 sectors, namely: Sector-5, Sector-12, Sector-17, Sector-18, Sector-19, Sector-21, Sector-22, and Sector-25. Group-4 consists of 8 sectors, namely: Sector-3, Sector-6, Sector-20, Sector-26, Sector-27, Sector-28, Sector-29, and Sector-30.

Sectors included in Group-1 should be prioritized in development planning as the sectors had strong FL and strong BL. These sectors are known as the key sectors. Second priorities in sectoral development depended on either FL or BL. Sectors in Group-2, if strong FL is the main concern, however, sectors in Group-3, if strong $\mathrm{BL}$ is the main concern. Sectors in Group- 4 were sectors that classified as non-priority sectors in development as these sectors had weak FL as well as weak BL.

\subsection{Intercountry-Linkages: Spill-over and Feedback Effects}

Figure 3 presents spill-over and feed-back effects in Indonesian economy for year 2000, 2005, 2010 and 2014. Panel-A presents spill-over and feed-back effects in Indonesian economy for year 2000. In year 2000, average total output multiplier in Indonesian economy was 2.0564; 80.26 per cent occurred in own country and 19.74 per cent occurred in other countries. By definition, spill-over effect is multiplier occurred in other countries. Total spill-over in year 2000 was 19.74 per cent; 1.07 per cent multipliers went to China, 0.31 per cent to India, 3.39 per cent to Japan, 1.12 per cent Korea, 0.46 per cent to Taiwan, 0.94 per cent to Australia, and 1.51 per cent to USA. If spill-over to the Rest of the World
(RoW) was ignored as no specific country was mentioned, three important countries received highest spill-over effect from Indonesia, namely: Japan (3.39\%), the United States (1.51\%) and Korea (1.12\%). Meanwhile, feed-back effect to Indonesian economy was only 0.12 per cent.

Panel-B presents Spill-Over and Feed-Back linkages in Indonesian economy for year 2005. In year 2005, total output multiplier in Indonesian economy was $2.0776 ; 79.75$ per cent occurred in own country and 20.25 per cent occurred in other countries. This means that 20.25 per cent of total output multipliers spilled-over to other countries. In this year, multiplier occurred in China was increased to 2.11 per cent, multiplier occurred in India was also increased to 0.48 per cent. However, multipliers occurred in (spill-over effects to) Japan, Korea, Taiwan, Australia and the United States was decreased consecutively to 2.39 per cent, 0.96 per cent, 0.36 per cent, 0.92 per cent and 0.91 per cent. Three important countries received highest spill-over effect from Indonesia, namely: Japan (2.39\%), China (2.11 $\%)$, and Korea (0.96 \%). Meanwhile, feed-back effect to Indonesian economy was only 0.14 per cent.

Panel-C presents Spill-Over and Feed-Back linkages in Indonesian economy for year 2010. In year 2010, total output multiplier in Indonesian economy was 2.1136 ; 81.81 per cent occurred in own country and 18.19 per cent occurred in other countries. This means that 18.19 per cent of total output multipliers spilled-over to other countries. In this year, multiplier occurred in (spill-over to) China was increased to 2.88 per cent, and multiplier occurred in Taiwan was also increased to 0.41 per cent. However, multipliers occurred in India, Japan, Korea, Australia and the United States was decreased consecutively to 0.37 per cent, 1.87 per cent, 0.94 per cent, 0.52 per cent, and 0.84 per cent. Three important countries received highest spill-over effect from Indonesia, namely: China (2.88 \%), Japan (1.87\%), and Korea (0.94\%). Meanwhile, feed-back effect to Indonesian economy was only 0.15 per cent. 


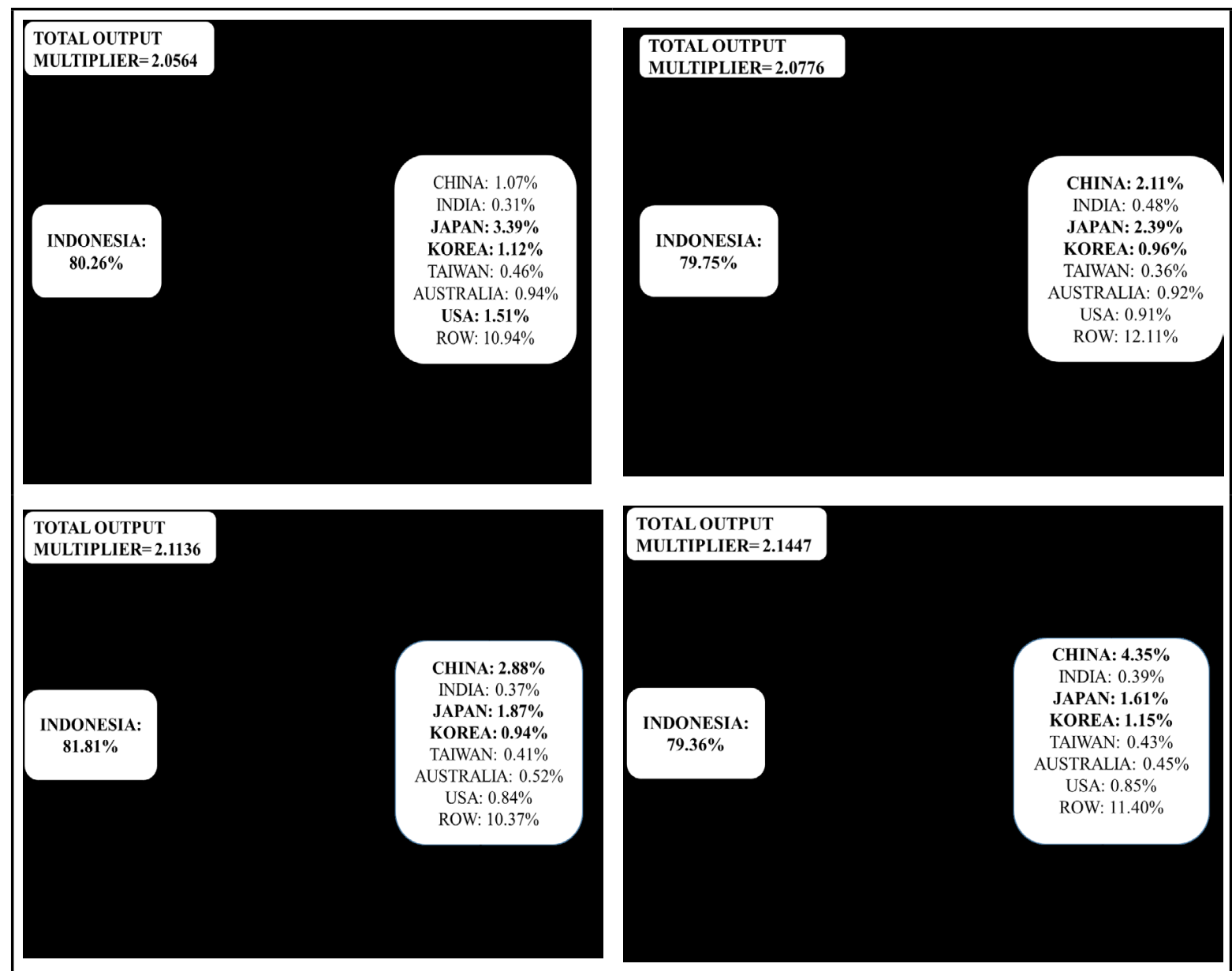

Figure 3: Spill-Over and Feed-Back Effects in Indonesian Economy: 2000, 2005, 2010, and 2014

Panel-D presents Spill-Over and Feed-Back linkages in Indonesian economy for year 2014. In year 2014, total output multiplier in Indonesian economy was $2.1447 ; 79.36$ per cent occurred in own country and 20.64 per cent occurred in other countries. This means that 20.64 per cent of total output multipliers spilled-over to other countries. In this year, multiplier occurred in (spill-over to) China was increased to 4.35 per cent, multiplier occurred in India increased to 0.39 per cent, in Korea increased to 1.15 per cent, in Taiwan increased to 0.43 per cent, and the United States increased to 0.54 per cent. However, multipliers occurred in Japan, and Australia was decreased consecutively to 1.61 and 0.45 per cent. Three important countries received highest spill-over effect from Indonesia, namely: China (4.35\%), Japan (1.61 \%), and Korea (1.15 \%). Meanwhile, feed-back effect to Indonesian economy was only 0.15 per cent.

Inter-Country Feed-back (ICFB) index and Feed-back and Spill-over (FBSO) indices indicate the importance of inter-country connection for a country could be shown by calculating output forthcoming from sectors in a country in response to a change in that county's final demands. The overall percentage error of ignoring inter-country linkages is measured by ICFB and FBSO indices. Table 5 presents ICFB and FBSO index in Indonesian sector economy for year 2000, 2005, 2010 and 2014. It is evident that at national level average ICFB indices were very small (0.0007) in year 2000, 0.0008 in year 2005, 0.0009 in year 2010 and 0.0009 in year 2014). The FBSO, however, were quite significant due to the large spill-over effects of multipliers. Average FBSO 
Jurnal Ekonomi Pembangunan: Kajian Masalah Ekonomi dan Pembangunan, 20 (2), 2019, 232-245

was 0.1980 in year 2000, 0.2031 in year 2005, 0.1826 in year 2010 and 0.2071 in 2014. Ignoring inter-country feed-back and spill-over effects would underestimate multipliers by 19.8 per cent in year 2000, 20.31 per cent in year 2005, 18.26 per cent in year 2010 and 20.71 per cent in year 2014.

\subsection{Discussion}

This section highlights some important findings. Firstly, in Indonesian economy BL was stronger than FL. There were more sectors with $\mathrm{BL}>1$ (Group-3) than sector with FL $>1$ (Group-2). In year 2000, there were 14 sectors with $\mathrm{BL}>1$ and only 1 sector with FL $>1$. In year 2005, there were 15 sectors with $\mathrm{BL}>1$ and no one sector with FL > 1. In year 2010 and 2014, FL was getting stronger. In year 2010, there were 8 sectors with $\mathrm{BL}>1$ and 5 sectors with $\mathrm{FL}>1$. The same numbers are with $\mathrm{BL}>1$ and $\mathrm{FL}>1$ in year 2014.

Secondly, the sectoral structures in Indonesian economy have significantly changed during 2000-2005 and 2010-2014. Small number of key sector in Indonesian economy as in year 2000 only one sector had FL $>1$ and $\mathrm{BL}>1$ included in Group-1. Event, no one key sector in year 2005 as no sector included in Group-1. But in year 2010, there 8 were sectors included in Group-1 (FL $>1$ and BL $>1$ ). The same numbers of sectors were included in Group-1 in year 2014.

Thirdly, spill-over effects were significantly importance in Indonesia economy, as in average, around 20 per cent multipliers occurred in other countries: $19.74 \%$ per cent in year $2000 ; 20.25 \%$ per cent in year $2005 ; 18.19 \%$ per cent in year 2010 and $20.64 \%$ per cent in year 2014. Three important countries where received the highest spill-over from Indonesia were Japan, the United States and Korea in year 2000; Japan, China and Korea in year 2005; China, Japan and Korea in 2010 and China, Japan and Korea in year 2014. Only small feed-back effects in Indonesian economy; at national average, 0.12 per cent in year 2000; 0.14 per cent in year 2005; 0.15 per cent in year 2010 and 0.15 per cent in year 2014 .
Finally, ignoring inter-country model would be misleading. Error created due to ignoring spillover and feed-back effects in analyzing linkages was 19.80 per cent in year 2000, 20.31 per cent in year 2005, 18.26 per cent in year 2010 and 20.71 per cent year 2014 .

\section{Conclusions}

From results and discussion it could be concluded that firstly sectoral-linkages through forward and backward analysis were important method in determining key sectors, but ignoring spill-over and feed-back effects could be misleading. It is suggested that sectors included in Group-1 be prioritized in economic development because they havestrong BL and FL as well. Secondly, spatial or inter-country spill-over and feed-back effects were significantly important in Indonesian economy. Ignoringinter-country input-output model will be resulting significant error. In Indonesian case, the error was about 20 per cent in average; 19.80 per cent in year 2000 , 20.31 per cent in year 2005, 18.26 per cent in year 2010 and 20.71 per cent year 2014. Three important countries where received the highest spill-over from Indonesia were Japan, the United States and Korea in year 2000; Japan, China and Korea in year 2005; China, Japan and Korea in 2010 and China, Japan and Korea in year 2014. As the spill-over from Indonesia to China tend to increase the year of study, a trade policy between Indonesia and China should be formulated carefully.

\section{Acknowledgement}

Authors thank to the Editors and two anonymous reviewers for their valuable comments on earlier versions of the paper.

\section{References}

Andreosso-O'Callaghan, B., \& Yue, G. (2004). Intersectoral linkages and key sectors in China, 1987-1997. Asian Economic Journal, 18(2), 165-183.

Baldwin, R., \& Lopez-gonzalez, J. (2014). Supply- 
Jurnal Ekonomi Pembangunan: Kajian Masalah Ekonomi dan Pembangunan, 20 (2), 2019, 232-245

chain Trade: A Portrait of Global Patterns and Several Testable Hypotheses. (October 2012). https://doi.org/10.1111/twec.12189

Beyers, W. B. (1976). Empirical identification of key sectors: some further evidence. 8(1936), 231-236. https://doi.org/https:// onlinelibrary.wiley.com/doi/full/10.1111/ twec. 12189.

Cai, J., \& Leung, P. (2004). Linkage Measures : a Revisit and a Suggested Alternative Linkage Measures: a Revisit and a Suggested. Economic Systems Research, 16 (March 2004), 37-41. https://doi. org/10.1080/0953531032000164800

Cai, J., Leung, P., Pan, M., \& Pooley, S. (2005). Economic linkage impacts of Hawaii's longline fishing regulations. 74, 232-242. https://doi.org/10.1016/j. fishres.2005.02.006

Cella, G. (1984). The Input-output Measurement of Interindustry Linakges. Oxford Bulletin of Economics and Statistics, 46(1 (1984) 0305-9049), 73-84. Retrieved from https://onlinelibrary.wiley.com/ doi/abs/10.1111/j.1468-0084.1984. mp46001005.x

Cochrane, S. G. (1990). from the SAGE Social Science Collections . All Rights Reserved. International Regional Science Review, 13(1\&2), 183-203. Retrieved from http://journals.sagepub.com/ doi/10.1177/016001769001300112

Costinot, A., \& Rodríguez-clare, A. (2018). The US Gains From Trade: Valuation Using the Demand for Foreign Factor Services. Journal of Economic Perspectives, 32(2), 3-24. Retrieved from https://www.aeaweb. org/articles?id=10.1257/jep.32.2.3

Dhehibi, B., Bahri, H., \& Annabi, M. (2012). Input and output technical efficiency and total factor productivity of wheat production in Tunisia. AfJARE, 7(1).

Dhingra, S., Huang, H., Ottaviano, G., Sampson,
T., \& April, J. V. R. (2016). The consequences of Brexit for UK trade and living standards. (2013).

di Mauro, F., Plamper, H., \& Stehrer, R. (2013). Global Value Chains: A Case for Europe to Cheer Up. Retrieved from https://www. ecb.europa.eu/home/pdf/research/compnet/ policy_brief_3_global_value_chains. pdf?fcccc5651bee912e1698e1019c8b3969.

Dietzenbacher, E. (2002). Interregional Multipliers: Looking Backward, Looking Forward. (June 2012), 37-41. https://doi. org/10.1080/00343400220121918

Dietzenbacher, E., \& Linden, J. A. Van Der. (1997). Sectoral and Spatial Linkages in the EC Production Structure *. 37(2), 235-257. Retrieved from https://onlinelibrary.wiley. com/doi/abs/10.1111/0022-4146.00053

Foster-mcgregor, N., Stehrer, R., \& de Vries, G. J. (2013). Offshoring and the skill structure of labour demand. Review World Economic. https://doi.org/10.1007/s10290-013-0163-4

Guccione, A., Gillen, W. J., Blair, P. D., \& Millert, R. E. (1988). Interregional feedbacks in input-output models: the least upper bound*. 28(3), 303-304. Retrieved from https://onlinelibrary.wiley.com/doi/ abs/10.1111/j.1467-9787.1988.tb01090.x

Hewings, G. J. D. (1982). The Empirical Identification of Key Sectors in an Economy: a Regional Perspective. Developing Economies,., Developing Economies, (20), 173-195. Retrieved from https://onlinelibrary.wiley.com/ doi/full/10.1111/j.1746-1049.1982. tb00444.x\#references-section

Hewings, G. J. D., Fonseca, M., \& Sonis, M. (1989). Key Sectors and Structural Change of Brazilian Economy: A Comparison of Alternative Approaches ancl Their Policy Implications. Journal of Policy Modeling, 11(1), 67-90. Retrieved from https:// www.sciencedirect.com/science/article/ 
Jurnal Ekonomi Pembangunan: Kajian Masalah Ekonomi dan Pembangunan, 20 (2), 2019, 232-245

pii/0161893889900252

Hoen, A. R. (2002). Identifying Linkages with a Cluster-based Methodology. Economic Systems Research, (September). https://doi. org/10.1080/09535310220140933

Johnson, R. C. (2014). Five Facts about ValueAdded Exports and Implications for Macroeconomics and Trade Research. 28(2), 119-142. Retrieved from https:// www.aeaweb.org/articles?id=10.1257/ jep.28.2.119

Jones, L. P. (1976). The Measurement of Hirschmanian Linkages. The Quarterly Journal of Economics, 90(2), 323-333. https://doi.org/http://journals.sagepub.com/ doi/abs/10.1068/a080231

Koopman, R., Wang, Z., \& Wei, S. (2014). Tracing Value-Added and Double Counting. 104(2), 459-494. https://doi.org/10.1257/ aer.104.2.459

Leung, P., \& Pooley, S. A. M. (2002). Regional Economic Impacts of Reductions in Fisheries Production: A Supply-Driven Approach University of Hawaii at Manoa. 16, 251-262. Retrieved from http://imina. soest.hawaii.edu/PFRP/reprints/leung_ regional_2001.pdf

Los, B., Timmer, M. P., \& Vries, G. J. De. (2014). How Global Are Value Chains? A New Approach to Measure International Fragmentation *. Journal of Regional Science, 55(1), 66-92. https://doi. org/10.1111/jors. 12121

Midmore, P., Munday, M., Roberts, A., Ã, P. M., Munday, M. A. X., \& Roberts, A. (2006). input - output tables Assessing Industry Linkages Using Regional Input - Output Tables. (August 2006), 37-41. https://doi. org/10.1080/00343400600631673

Miller, R. E. (1966). Interrgional Feedback in Input-Output Models: Some Preliminary Results. Papers of the Regional Science Association. Retrieved from https:/link.
springer.com/article/10.1007/BF01982512

Miller, R. E. (1986). Upper Bounds on the Sizes of Interregioma Feedbacks in Multiregional Input-output Models *. 26(2). Retrieved from https://www.researchgate.net/ publication/229444863_Upper_Bounds_ on_the_Sizes_of_Interregional_Feedbacks_ in_Multiregional_Input-Output_Models

Miller, R. E., \& Blair, P. D. (2009). Input-Output Analysis:Foundation and Extensions (Second Edi).

Miller, R. E., \& Lahr, M. (2001). ATaxonomy of Extractions. In In Regional Science Perspectives in Economic Analysis: A Festsbrift in Memory of Benyamin H. Stevens (pp. 407-441). https://doi.org/https:// books.google.ht/books/about/Regional_ Science_Perspectives_in_Economi. html?hl=fr\&id=SriWDBY077EC\&utm_ source=gb-gplus-shareRegional

Rashid, A. (2004). Sectoral Linkages ; Identifying the Key Growth Stimulating Sector of the Pakistan Economy Sectoral Linkages; Identifying the Key Growth Stimulating Sector of the Pakistan Economy. (27210). Retrieved from https://core.ac.uk/ display/38625536

Rueda-Cantuche, J., Neuwahl, F. V. R., \& Delgado, L. (2012). The Adjustment Capacity of the European Economy Examined with an Input-Output Based Key Sector Analysis. 67436 .

Saito, M., Ruta, M., \& Turunen, J. (2013). Trade Interconnectedness : The World with Global Value Chains.

Sonis, M., \& Hewings, G. J. D. (2009). Coefficient Change and Innovation Spread in Input Output Models. IIOA Working Papers in Input-Output Economics, WPIOX 09-0, $1-22$.

Sonis, M., Hewings, J. D., \& Guo, J. (2000). A New Image of Classical Key Sector Analysis : Minimum Information Decomposition 
of the Leontief Inverse A New Image of Classical Key Sector Analysis : Economic Systems Research, 12(3). https://doi. org/10.1080/09535310050120952

Timmer, M. P., Dietzenbacher, E., Los, B., \& Stehrer, R. (2015). An Illustrated User Guide to the World Input - Output Database: the Case of Global Automotive Production. 23(3), 575-605. https://doi. org/10.1111/roie. 12178

Timmer, M. P., Los, B., Stehrer, R., \& De Vries, G. J. De. (2016). An Anatomy of the Global Trade Slowdown based on WIOD 2016 Release. Retrieved from http://www.ggdc. net/publications/memorandum/gd162.pdf

Timmer, M. P., Los, B., Stehrer, R., \& de Vries, G. (2013). Fragmentation, incomes and jobs: an analysis of European competitiveness. Economic Policy, (October 2013), 615-669. Retrieved from https://academic.oup.com/ economicpolicy/article-abstract/28/76/613/2 918413?redirectedFrom=fulltext

United Nation. (2018). Handbook on Supply , Use and Input- Output Tables with Extensions and Applications. Retrieved from http://ec.europa.eu/eurostat/ documents/51957/51999/Handbook+on+Su pply $\% 2 \mathrm{C}+$ Use+and+Input-Output+Tables +with+Extensions+and+Applications

Wang, Z., Zhu, K., \& Wei, S.-J. (2018). Quantifying International Production Sharing at Bilateral and Sector Levels. Retrieved from http://www.nber.org/papers/w19677 


\section{Appendixes.}

Appendix-1:

Sector Classifications

\begin{tabular}{|c|c|}
\hline Sector Code & Descriptions \\
\hline Sector-1 & $\begin{array}{l}\text { Crop and animal production, forestry, fishing } \\
\text { and aquaculture }\end{array}$ \\
\hline Sector-2 & Forestry and logging activities \\
\hline Sector-3 & Fishing and aquaculture \\
\hline Sector-4 & Mining and quarrying \\
\hline Sector-5 & $\begin{array}{l}\text { Manufacture of wood and of products of wood } \\
\text { and cork, except furniture }\end{array}$ \\
\hline Sector- 6 & Manufacture of paper and paper products \\
\hline Sector-7 & Printing and reproduction of recorded media \\
\hline Sector-8 & $\begin{array}{l}\text { Manufacture of coke and refined petroleum } \\
\text { products }\end{array}$ \\
\hline Sector-9 & Manufacture of chemicals and chemical products \\
\hline Sector-10 & $\begin{array}{l}\text { Manufacture of basic pharmaceutical products } \\
\text { and pharmaceutical preparations }\end{array}$ \\
\hline Sector-11 & Manufacture of rubber and plastic products \\
\hline Sector-12 & $\begin{array}{l}\text { Manufacture of other non-metallic mineral } \\
\text { products }\end{array}$ \\
\hline Sector-13 & Manufacture of basic metals \\
\hline Sector-14 & $\begin{array}{l}\text { Manufacture of fabricated metal products, except } \\
\text { machinery and equipment }\end{array}$ \\
\hline Sector-15 & $\begin{array}{l}\text { Manufacture of computer, electronic and optical } \\
\text { products }\end{array}$ \\
\hline Sector-16 & Manufacture of electrical equipment \\
\hline Sector-17 & $\begin{array}{l}\text { Manufacture of machinery and equipment not } \\
\text { elsewhere classified }\end{array}$ \\
\hline Sector-18 & $\begin{array}{l}\text { Manufacture of motor vehicles, trailers and } \\
\text { semi-trailers }\end{array}$ \\
\hline Sector-19 & Manufacture of other transport equipment \\
\hline Sector-20 & Manufacture of furniture; other manufacturing \\
\hline Sector-21 & $\begin{array}{l}\text { Repair and installation of machinery and } \\
\text { equipment }\end{array}$ \\
\hline Sector- 22 & $\begin{array}{l}\text { Electricity, gas, steam and air conditioning } \\
\text { supply }\end{array}$ \\
\hline Sector-23 & $\begin{array}{l}\text { Water collection, treatment and supply; } \\
\text { Sewerage \& waste: collection, treatment and } \\
\text { disposal }\end{array}$ \\
\hline Sector-24 & Electricity, gas and drinking water \\
\hline Sector-25 & Construction \\
\hline Sector-26 & $\begin{array}{l}\text { Wholesale and retail trade and repair, } \\
\text { accommodation and food service activities }\end{array}$ \\
\hline Sector-27 & $\begin{array}{l}\text { Transportation, telecommunication, information } \\
\text { and publication }\end{array}$ \\
\hline Sector-28 & Real estate, financial and corporate services \\
\hline
\end{tabular}


Avalaible online at http://journals.ums.ac.id, Permalink/DOI: 10.23917/jep.v20i2.9057

Jurnal Ekonomi Pembangunan: Kajian Masalah Ekonomi dan Pembangunan, 20 (2), 2019, 232-245

\begin{tabular}{cl}
\hline Sector Code & \multicolumn{1}{c}{ Descriptions } \\
\hline Sector-29 & $\begin{array}{l}\text { Legal \& management consultancy, architectures } \\
\text { \& engineering, scientific research \& development }\end{array}$ \\
Sector-30 & Other service activities \\
\hline \multicolumn{2}{c}{ Source: Aggregated from WIOT, 2016 }
\end{tabular}

Source: Aggregated from WIOT, 2016

Appendix-2:

Inter-Sector Linkages in Indonesia Economy: 2000, 2005, 2010, 2014

\begin{tabular}{|c|c|c|c|c|c|c|c|c|}
\hline \multirow{2}{*}{$\begin{array}{l}\text { Country } \\
\text { Sector }\end{array}$} & \multicolumn{2}{|c|}{2000} & \multicolumn{2}{|c|}{2005} & \multicolumn{2}{|c|}{2010} & \multicolumn{2}{|c|}{2014} \\
\hline & $\mathrm{FL}^{*}$ & $\mathrm{BL}^{* *}$ & $\mathrm{FL}^{*}$ & $\mathrm{BL}^{* *}$ & $\mathrm{FL}^{*}$ & $\mathrm{BL}^{* *}$ & $\mathrm{FL}^{*}$ & $\mathrm{BL}^{* *}$ \\
\hline S-1 & 0.5252 & 0.3880 & 0.3980 & 0.4233 & 1.0367 & 0.3131 & 1.0020 & 0.3127 \\
\hline S-2 & 1.0126 & 0.3457 & 0.6383 & 0.2872 & 1.5255 & 0.2425 & 1.4955 & 0.2422 \\
\hline S-3 & 0.2279 & 0.3996 & 0.1806 & 0.3115 & 0.6198 & 0.2568 & 0.6244 & 0.2566 \\
\hline S- 4 & 0.6570 & 0.2514 & 0.5649 & 0.3055 & 1.5864 & 0.4545 & 1.5612 & 0.4532 \\
\hline S-5 & 0.2910 & 1.1271 & 0.2272 & 1.1104 & 0.6525 & 1.1577 & 0.6505 & 1.1562 \\
\hline S-6 & 0.4654 & 1.1019 & 0.3488 & 1.0851 & 0.4113 & 0.9933 & 0.3322 & 0.9911 \\
\hline S-7 & 0.9378 & 1.0878 & 0.5980 & 0.9739 & 1.5311 & 0.9890 & 1.5176 & 0.9873 \\
\hline S-8 & 1.0058 & 1.1525 & 0.6382 & 1.0773 & 1.5564 & 1.1220 & 1.5227 & 1.1194 \\
\hline S-9 & 0.4562 & 0.8723 & 0.4846 & 1.0808 & 1.5993 & 1.2237 & 1.5706 & 1.2212 \\
\hline S-10 & 0.6193 & 0.8647 & 0.6660 & 0.7009 & 1.2103 & 0.9141 & 1.2073 & 0.9101 \\
\hline S-11 & 0.6408 & 1.1218 & 0.5814 & 1.1757 & 1.4789 & 1.1123 & 1.4446 & 1.1081 \\
\hline S-12 & 0.1708 & 1.1316 & 0.1687 & 1.2022 & 0.7516 & 1.1241 & 0.7616 & 1.1217 \\
\hline S-13 & 0.4877 & 1.1506 & 0.3957 & 1.2328 & 1.3037 & 1.2471 & 1.3102 & 1.2427 \\
\hline S-14 & 0.5386 & 0.9732 & 0.5315 & 0.9193 & 1.4260 & 1.1030 & 1.4089 & 1.0996 \\
\hline S-15 & 1.2971 & 1.2342 & 1.2861 & 1.2703 & 1.5842 & 1.1544 & 1.5578 & 1.1510 \\
\hline S-16 & 0.9256 & 1.1204 & 0.6978 & 1.0656 & 1.5299 & 1.0861 & 1.5014 & 1.0850 \\
\hline S-17 & 0.3373 & 1.1897 & 0.2166 & 1.0981 & 0.6255 & 1.2448 & 0.5948 & 1.2443 \\
\hline S-18 & 0.4561 & 1.1194 & 0.3578 & 1.0836 & 0.9153 & 1.1618 & 0.9171 & 1.1609 \\
\hline S-19 & 0.3923 & 1.1539 & 0.3414 & 1.2423 & 0.8517 & 1.2553 & 0.8529 & 1.2530 \\
\hline S-20 & 0.2182 & 0.9266 & 0.0980 & 0.9712 & 0.6965 & 0.8642 & 0.6486 & 0.8620 \\
\hline S-21 & 0.3489 & 1.1493 & 0.5544 & 1.1507 & 0.9548 & 1.0064 & 0.8700 & 1.0218 \\
\hline S-22 & 0.1545 & 1.1664 & 0.2199 & 1.0954 & 0.4281 & 1.0375 & 0.3846 & 1.0354 \\
\hline S-24 & 0.4107 & 1.2493 & 0.4859 & 1.1941 & 1.1147 & 1.2888 & 1.0792 & 1.2898 \\
\hline S-25 & 0.0143 & 1.1254 & 0.0123 & 1.0927 & 0.1408 & 1.1137 & 0.1360 & 1.1116 \\
\hline S-26 & 0.4769 & 0.7458 & 0.3358 & 0.7103 & 0.8357 & 0.6472 & 0.8207 & 0.6494 \\
\hline S-27 & 0.3249 & 0.9838 & 0.3589 & 0.8741 & 0.8308 & 0.8243 & 0.7952 & 0.8568 \\
\hline S-28 & 0.3793 & 0.5301 & 0.4063 & 0.6836 & 0.5855 & 0.5345 & 0.5991 & 0.5369 \\
\hline S-29 & 0.0354 & 0.7649 & 0.1375 & 0.8804 & 0.1250 & 0.7156 & 0.1300 & 0.7124 \\
\hline S-30 & 0.1593 & 0.5537 & 0.0958 & 0.4880 & 0.6558 & 0.8588 & 0.6540 & 0.8587 \\
\hline
\end{tabular}

${ }^{*} \mathrm{FL}=$ Forward Linkages $; *$ BL $=$ Backward Linkages 